\title{
Implementation of Fisheries Resources Protection from Illegal Unreported and Unregulated Fishing Practices
}

\author{
Mansur Armin Bin Ali*, Rosdian, Rahmayani Amrullah
}

Faculty of Law, Tadulako University, Indonesia

DOI: $10.36348 /$ sijlcj.2020.v03i11.009

| Received: 05.11.2020 | Accepted: 16.11.2020 | Published: 19.11.2020

*Corresponding author: Mansur Armin Bin Ali

\section{Abstract}

Illegal fishing practices, unreported and unregulated fishing (IUU fishing) have a negative impact on the economy, ecology, state sovereignty and social problems for Indonesia. According to FAO data, the economic loss suffered by Indonesia due to IUU fishing is around Rp. 30 trillion per year. This study aims to find forms of fishery resource protection that have been carried out by the central and local governments, and to find forms of law enforcement to eradicate IUU fishing that have been carried out by law enforcement officials. This research is a socio-juridical research, using a statutory approach and a conceptual approach, the data used are primary data and secondary data, all data collected were analyzed qualitatively. The results showed that the concept of protecting fishery resources from the ideal IUU fishing practice in Indonesia is to empower coastal communities by considering ecological, socio-economic and socio-cultural aspects, while community welfare is carried out by reducing imbalances in the management of fishing fleets, availability of fishing port infrastructure, chain fishery food management, research development and utilization, fishing community participation, and central and regional arrangements.

Keywords: Fishery resources, IUU fishing, protection.

Copyright (C) 2020 The Author(s): This is an open-access article distributed under the terms of the Creative Commons Attribution 4.0 International License (CC BY-NC 4.0) which permits unrestricted use, distribution, and reproduction in any medium for non-commercial use provided the original author and source are credited.

\section{INTRODUCTION}

In the regional context, Indonesia is geographically very strategic. Indonesia is a cross between the continents of Asia and Australia, the Indian Ocean and the Pacific. Indonesia is the biggest archipelago country in the world [1]. Illegal fishing practices, unreported and unregulated fishing (IUU fishing) have a negative impact on the economy, ecology, state sovereignty and social problems for Indonesia. According to FAO data, the economic loss suffered by Indonesia due to IUU fishing is around Rp. 30 trillion per year. According to Suhana [2] Economic losses directly result in reduced contribution from capture fisheries to GDP, reduced/lost employment in the fisheries sector, reduced state income from exports, reduced state income from the tax sector, and no multiplayer effects from fishing industry activities. From the ecological aspect, IUU fishing has a bad impact on the damage to the fishery ecosystem due to overfishing which causes sustainable fisheries development to be stopped [3].

This phenomenon is also followed by the increase in IUU fishing practices that threaten the sustainability of fish resources and the environment. This condition encourages member countries of the Food and Agriculture Organization (FAO) to formulate references that can be applied by countries in the world regarding the management and development of fisheries in an orderly, responsible and sustainable manner. Among them is through The Code of Conduct for Responsible Fisheries (CCRF) which was agreed in 1995.

However, in its development, the implementation of CCRF is considered insufficient as an instrument in fisheries resource management, including the prevention and control of IUU fishing. Therefore, FAO member countries have formulated and agreed on international action to combat IUU fishing as outlined in the International Plan of Action to Prevent, Deter and Eliminate IUU Fishing (IPOA-IUU Fishing) in 2001. IPOA-IUU Fishing is an action plan global in order to prevent damage to fishery resources and rebuild fishery resources that have been or are almost extinct, so that the supply of food sourced from fisheries for current and future generations can be guaranteed. The IPOA-IUU Fishing must be followed up by every country, including Indonesia, by compiling 
an action plan to prevent and combat IUU fishing at the national level [4].

At the level of national law, Indonesia has enacted Republic of Indonesia Law Number 31 Year 2004 concerning Fisheries which was later amended by Law of the Republic of Indonesia Number 45 Year 2009 concerning Amendments to Law of the Republic of Indonesia Number 31 Year 2004 concerning Fisheries. However, the issue of legal substance is still a problem due to the low number of criminal sanctions provisions in punishing IUU fishing actors and the absence of a specific law that comprehensively regulates eradicating IUU fishing [5]. Based on the background of this problem, the main problem that will be discussed in this paper is what form of fishery resource protection has been carried out by the central and local governments? and what is the form of law enforcement to eradicate IUU fishing that has been carried out by law enforcement officials?

\section{RESEARCH METHOD}

This type of research is socio-juridical research [6] by using a statutory approach and a conceptual approach [7]. The data used is primary and secondary data obtained through library research and interview [8]. All data collected were then analyzed qualitatively.

\section{RESULTS AND DISCUSSION}

State as the main subject in international law [9] some of them have oceans. The territorial sea of the Dutch East Indies or Indonesian territorial sea is a sea route that extends towards the sea up to a distance of 3 nautical miles measured from the low water line on each island or part of the island which is the Indonesian mainland. Thus the territorial waters of Indonesia include sea routes that surround each island or part of the Indonesian island which is only 3 nautical miles wide. Because each island or part of the island has its own territorial sea with a width of only 3 nautical miles from the low water line of each island or part of the island, this results in the formation of spaces and pockets of free sea or international waters. between one island or part of an island with another island or part of another island, so that it has a very negative and detrimental impact on Indonesia's sovereignty and territorial integrity [10]. The right to control the state in Article 33 of the 1945 Constitution, justifies the state to exploit natural resources related to public utilities and public services. On the basis of philosophical considerations (the basic spirit of the economy is joint and kinship), strategic (public interest), political (preventing monopolies and oligopolies that are detrimental to the state economy), economy (efficiency and effectiveness), and for the general welfare and the greatest possible prosperity of the people.

The detrimental impact of the colonial legal arrangement (TZMKO) which breathed freedom at sea (freedom of the seas) had to be stopped or overcome, through the regulation of national law. This has been initiated since the Proclamation of Independence of the Republic of Indonesia on August 17, 1945, the birth of the 1945 Constitution on August 18, 1945 in which there are Transitional Rules (Article II), and was followed by the issuance of the Juanda Declaration on December 13, 1957, which was the government's announcement. regarding Indonesian territorial waters. This declaration states that all waters around, between and connecting islands or parts of islands belonging to the mainland of the Republic of Indonesia, regardless of the size or width of the Republic of Indonesia are reasonable parts of the land area of the Republic of Indonesia and thus constitute part of the national waters which are under the absolute sovereignty of the Republic of Indonesia [11]. State control right means that the state through the government has the authority to determine the use, utilization and rights of natural resources within the scope of regulating, managing, managing and supervising the management and utilization of natural resources. Therefore, natural resources which are important for the state and control the needs of many people, because they are related to public utilities and public services, must be controlled by the state and run by the government. This is because these natural resources must be enjoyed by the people in a just, affordable manner, in an atmosphere of prosperity and general welfare that is just and equitable.

Considerations for establishing the Code of Conduct for Responsible Fisheries by the Food and Agriculture Organization of the United Nations (FAO) [12] this is because fishing has always been a major source of food for humans and a provider of employment and economic benefits for those involved in this activity. But increasing knowledge and fisheries development has blurred this view in the face of the fact that fish resources, although renewable, are not unlimited, because they need to be managed fairly so that their contribution to nutrition, economy and social welfare of the world's population can be sustainable [13]. The state control rights stated in Article 33 of the 1945 Constitution position the state as the regulator and guarantor of the people's welfare. The functions of the state cannot be separated from one another, meaning that the release of a business sector over natural resources to cooperatives, the private sector must be accompanied by special forms of regulation and supervision, therefore the obligation to realize the greatest prosperity of the people can still be controlled by the state.

The phenomenon of increasing Illegal, Unreported, and Unregulated (IUU) fishing practices that threatens the sustainability of fish resources and the marine environment, encourages member countries of the Food and Agriculture Organization (FAO) to formulate references that can be applied by countries in the world regarding management and development and 
orderly, responsible and sustainable fisheries. Among them is the Code of Conduct for Responsible Fisheries (CCRF) which was agreed in 1995. In its development, the implementation of CCRF is considered insufficient as an instrument in fisheries resource management, including the prevention and control of IUU fishing. Therefore, FAO member countries have formulated and agreed on international action to reduce IUU fishing as outlined in the International Plan of Action to Prevent, Deter, and Eliminate IUU Fishing (IPOA-IUU Fishing) in 2001. IPOA-IUU Fishing is global action in order to prevent damage to fishery resources and to rebuild fishery resources that have been or are almost extinct so that food needs that come from fisheries for current and future generations can be guaranteed. The IPOA-IUU Fishing must be followed up by every country, including Indonesia, by compiling an action plan to prevent and combat IUU fishing at the national level [14]. Although IPOA-IUU Fishing has provided limitations on the definition of IUU Fishing, in a simpler and operational sense, mentioning "illegal fishing" alone can be interpreted as illegal fishing activities. The definition of IUU fishing in the CCRF is [15]:

- Illegal fishing is fishing activity illegally in the waters of the territory or EEZ of a country, not having a permit from the coastal state;

- Unregulated fishing is a fishing activity in the territorial waters or EEZ of a country that does not comply with the rules in force in that country;

- Unreported fishing is a fishing activity in the territorial waters or EEZ of a country whose operations are not reported as well as data on ships and their catches

Illegal fishing activities that occur most frequently in Indonesian fisheries management areas are illegal fishing by foreign fishing vessels (KIA) from several neighboring countries (neighboring countries). Although it is difficult to map and estimate the level of Illegal Fishing that occurs in WPP-RI, from the results of the supervision so far (2005-2010) it can be said that illegal fishing by KIA mostly occurs in the EEZ (Exclusive Economic Zone) and also quite a lot occurs in archipelagic waters (Archipelagic State). In general, the types of fishing gear used by KIA or ex foreign vessels illegally in Indonesian waters are productive fishing gears such as purse seines and trawls. Illegal fishing activities are also carried out by Indonesian fishing vessels (KII) [16]. Currently, there appears to be a concrete and decisive action regarding illegal fishing. Especially seeing the work of the Minister of Maritime Affairs and Fisheries, Susi Pudjiastuti, who is very concerned about the issue of marine sovereignty and the welfare of fishermen in Indonesia. After three years in office, Minister Susi has sunk 317 foreign vessels that were proven to have entered Indonesian waters. The most recent is the sinking of 81 foreign ships that were proven to have stolen fish in the Indonesian sea area in
April 2017. The sinking was carried out simultaneously in various parts of the archipelago starting from Aceh, Pontianak, Bali, Sorong, Merauke, Belawan, Tarempa, Natuna, Tarakan, Bitung, Ternate. , and Ambon. The number of illegal fishing vessels that have been sunk since October 2014 to April 12017 is 317 vessels, with details of Vietnam 142 ships, Philippines 76 ships, Thailand 21 ships, Malaysia 49 ships, Indonesia 21 ships, Papua New Guinea 2 ships, China 1 ship, Belize 1 ship and without country 4 ships. This action is certainly very welcomed by the Indonesian people in general and fishermen in particular. This is what the community has been waiting for all this time, determination and seriousness in eradicating illegal fishing that has been troubling the public and destroying the potential of Indonesia's sea. That way, fishermen no longer feel cheated by illegal foreign vessels who often steal fish in Indonesian seas [17]. In relation to this dissertation study, the government has the authority to determine the use, utilization and rights of natural resources in the scope of regulating, managing, managing, and supervising the management and utilization of fishery resources, including by cracking down on the perpetrators of IUU Fishing so that fish availability for local fishermen can be fulfilled, so that coastal communities and fishermen can prosper.

\section{CONCLUSION}

The concept of protecting fishery resources from the ideal IUU fishing practice in Indonesia is to empower coastal communities by considering ecological, socio-economic and socio-cultural aspects, while community welfare is carried out by reducing imbalances in the management of fishing fleets, availability of fishing port infrastructure, chain fishery food management, research development and utilization, fishing community participation, and central and regional arrangements.

\section{REFERENCES}

1. Momentum Membangun Kejayaan Maritim, Majala Gatra, $41^{\text {st }}$ Ed.; Year XX, August 2014, p. 148-158.

2. Suhana. (2011). Ekonomi Politik Kebijakan Kelautan Indonesia: Gagasan-Gagasan PolitikPembangunan Negara Kepulauan Dan Reformasi Kelembagaan Yang Berbasis Kearifan Lokal, Malang: In-Trans Publising, p. 76-77.

3. Akhmad, S. (2010). Politik Hukum Kelautan dan Perikanan: Isu, Permasalahan dan Telaah Kritis Permasalahan, Bandung: Nuansa Aulia, p. 44-45.

4. KKP terbitkan Kepmen penanggulangan IUU fishing, Center for Statistical Data and Information, Ministry of Marine Affairs and Fisheries, KKP Press Release May 30, 2013, p. 1.

5. Dikdik, M. S. (2011). Hukum Laut Internasional dan Pengaturannya di Indonesia, Bandung: Refika Aditama, p. 164. 
6. Soerjono Soekanto and Sri Mamudji, Penelitian Hukum Normatif, Jakarta: Rajawali Pers, 2011, p. 14

7. Peter, M. M. (2010). Penelitian Hukum, Jakarta: Kencana Prenada Media Group, p. 96.

8. Kadarudin. (2020). Mengenal Riset dalam Bidang Ilmu Hukum: Tipologi, Metodologi, dan Kerangka, Ponorogo: Uwais Inspirasi Indonesia, p. 171.

9. Kadarudin. (2020). Antologi Hukum Internasional Kontemporer, Yogyakarta: Deepublish, p. 561.

10. Marcel, H. (2014). Hukum Laut Indonesia, Dari Sejarah Perkembangan Hingga Pengaturan Hukumnya, Makassar: Pustaka Pena Press, p. 19.

11. Ibid., p. 20-21
12. See http://www.fao.org/docrep/003/x9066e/x9066e01. htm

13. Marhaeni, S. S. (2010). Hukum Perikanan Nasional dan Internasional, Jakarta: Gramedia Pustaka Utama.

14. Dina, S. (2013). Port State Measures dalam Upaya Pencegahan Terhadap IUU Fishing di Indonesia, in Achmad Gusman Siswandi and Siti Noor Malia Putri (Ed.), Peran Hukum dalam Pemabngunan Indonesia, Kenyataan, Harapan, dan Tantangan, Bandung: PT. Remaja Rosdakarya, p. 441.

15. Ibid., p. 442

16. Ibid., p. 442-443

17. Hafizly. (2017). Sejahterakan Nelayan, Perangi Illegal Fishing, Pontianak Post. 